\title{
Distribution of ABO and Rh blood groups in Nepalese medical students
}

\author{
Upadhyay-Dhungel $\mathrm{K}^{1^{*}}$, Banskota GN², Das PK², Sohal $\mathrm{A}^{1}$ \\ Janaki Medical College, Janakpur, Nepal \\ Think Tank Foundation, Jorpati, Nepal
}

${ }^{1}$ Department of Physiology, Janaki Medical College, Janakpurdham, Nepal

${ }^{2}$ Department of Physiology, KIST Medical College, Nepal

*Director, Research and Planning, Think Tank Foundation, Nepal

\begin{abstract}
Background and Objectives: The distribution of $\mathrm{ABO}$ and Rh blood groups vary from population to population. With an interest of finding out rare blood group in Nepalese population, we studied the blood group distribution was studied in five different medical colleges in Nepal.

Material and Methods: Capillary Blood sample were taken to determine blood group of of 2208 twenty two hundred and eight Nepalese students from five different medical colleges, viz. Manipal College of medical sciences, Pokhara; Nepalgunj Medical College, Chisapani, Banke ; College of Medical sciences, Bharatpur, Chitwan; Kist Medical College, Lalitpur and Janaki Medical College, Janakpur were recorded. Slide test method was used to determine the blood group of the subjects.
\end{abstract}

Results: In our study subjects, $28.17 \%$ were blood group A, $30.17 \%$ were blood group B, 34.87\% were blood group $\mathrm{O}$ and $6.79 \%$ were blood group AB. Similarly, 95.38\% were $\mathrm{Rh}+\mathrm{ve}$ and $4.62 \%$ were $\mathrm{Rh}-\mathrm{ve}$. The blood group distribution patterns in male and female were different.

Conclusion: This result demonstrates that $\mathrm{AB}$ blood group is the most rare blood group among the studied Nepalese population, followed by group A, B and 0.

Keywords: Blood group, ABO, Rh, Nepalese students

\section{INTRODUCTION}

"Donate blood save life". This is a very popular slogan. Blood donation is becoming popular day by day as a social activity. Modern medicine uses blood and its products by transfusion. The ABO and Rh are the major (clinically significant) blood group antigens though almost 400 of them have been recognized. All of them if mismatched can cause hemolytic transfusion reaction. So, to avoid the danger of mismatched blood transfusion, the determination of blood groups of those involved in transfusion (donor and recipient) is the most. Among different blood grouping system, ABO and Rhesus system (Rh) is the most important one in blood transfusion. It is very interesting fact that there is an association between certain disorder like peptic ulcers, gastric cancer, thromboembolic diseases, cholera etc and particular blood group [1, 2]. This adds 
up the importance of knowing ones blood group in medicine.

It is also an established fact that distribution of blood groups varies from races to races. The frequency of blood groups $\mathrm{A}, \mathrm{B}, \mathrm{O}$ and $\mathrm{AB}$ in USA is $41 \%, 10 \%, 45 \%$ and $4 \%$ respectively [3]. About $85 \%$ of all white people are $\mathrm{Rh}+\mathrm{ve}$ and $15 \%$ are $\mathrm{Rh}$-ve. In American blacks, the percentage of $\mathrm{Rh}+\mathrm{ve}$ is about 95\% [4] and in Asians 99\% are Rh +ve [3]. Nepalese are racially different from other population. So, we were interested in finding out the rare blood group and the distribution of $\mathrm{ABO}$ and $\mathrm{Rh}$ groups among the Nepalese students in this medical college.

\section{MATERIALS AND METHODS}

Blood groups (ABO and Rh) of 2208 twenty two hundred and eight Nepalese students from five different medical colleges, viz. Manipal College of medical sciences, Pokhara; Nepalgunj Medical College, Chisapani, Banke ; College of Medical sciences, Bharatpur, Chitwan; Kist Medical College, Lalitpur and Janaki Medical College, Janakpur were recorded. Students themselves in guidance of faculty determine their blood group in physiology practical classes. They use slide test method to determine their blood group. For the determination of blood group of a subject, a drop of each anti sera, anti A, anti B, and anti $D$ is placed on three glass slides and slides were marked as anti $\mathrm{A}$, anti $\mathrm{B}$, anti D and placed above moist filter paper. Healthy prick was made on the ring finger of the subject and few drop of blood was mixed with saline and then placed in each marked slide with anti-sera. The blood/diluted blood drops was mixed with its respective anti sera using separate glass rods. The slide was observed for agglutination. The agglutination was confirmed by seeing under microscope (low power). ABO blood groups were determined on the basis of agglutination as shown in table 1. For Rh system: If agglutination occurred with anti $\mathrm{D}$, then the subject was $\mathrm{Rh}+\mathrm{ve}$, if not, s/he was Rh-ve.

Table 1: Guideline for determination of ABO blood group

\begin{tabular}{ccc}
\hline $\begin{array}{c}\text { Agglutination } \\
\text { with anti-A }\end{array}$ & $\begin{array}{c}\text { Agglutination } \\
\text { with anti-B }\end{array}$ & $\begin{array}{c}\text { Blood } \\
\text { group }\end{array}$ \\
\hline+ & - & $\mathrm{A}$ \\
- & + & $\mathrm{B}$ \\
- & - & 0 \\
+ & + & $\mathrm{AB}$ \\
\hline,+ agglutination \\
absent
\end{tabular}

\section{RESULTS}

The distribution of blood groups A, B, O and $\mathrm{AB}$ and also Rh groups are shown in Table 2. The rare blood group among our study subjects was AB $(6.79 \%$ only $)$ The commonest blood group was found to be 0 , followed by B then A.

Table 2: The distribution of ABO and Rh blood groups in whole study subjects

Number of students (percentage)

\begin{tabular}{cccc}
\hline $\begin{array}{c}\text { Blood } \\
\text { groups }\end{array}$ & Rh +ve & Rh $-\mathbf{v e}$ & Total \\
\hline $\mathrm{A}$ & $598(27.08 \%)$ & $24(1.09 \%)$ & $622(28.17 \%)$ \\
$\mathrm{B}$ & $638(28.90 \%)$ & $28(1.27 \%)$ & $666(30.17 \%)$ \\
$\mathrm{O}$ & $724(32.79 \%)$ & $46(2.08 \%)$ & $770(34.87 \%)$ \\
$\mathrm{AB}$ & $146(6.61 \%)$ & $4(0.18 \%)$ & $150(6.79 \%)$ \\
\hline Total & $2106(\mathbf{9 5 . 3 8 \% )}$ & $102(\mathbf{4 . 6 2 \%})$ & $2208(\mathbf{1 0 0 \%})$ \\
\hline
\end{tabular}


The percentage of $\mathrm{Rh}+\mathrm{ve}$ and $\mathrm{Rh}$-ve subjects were $95.38 \%$ and $4.62 \%$ respectively. There were differences in distribution of blood groupings between male and female which are shown in table 3 and 4 .

Table 3: The distribution of $\mathrm{ABO}$ and $\mathrm{Rh}$ blood groups in male subjects

Number of students (percentage)

\begin{tabular}{cccc}
\hline $\begin{array}{c}\text { Blood } \\
\text { group }\end{array}$ & Rh +ve & Rh -ve & Total \\
\hline & 364 & 14 & 378 \\
$\mathrm{~A}$ & $(24.17 \%)$ & $(0.93 \%)$ & $(25.10 \%)$ \\
& & & 470 \\
$\mathrm{~B}$ & $(30.68 \%)$ & $8(0.53 \%)$ & $(31.21 \%)$ \\
& & & \\
& 514 & 40 & 554 \\
$\mathrm{O}$ & $(34.13 \%)$ & $(2.66 \%)$ & $(36.79 \%)$ \\
& & & 104 \\
$\mathrm{AB}$ & $(6.90 \%)$ & $(0.00 \%)$ & $(6.90 \%)$ \\
& & & \\
\hline & 1444 & 62 & 1506 \\
Total & $(95.88 \%)$ & $(4.12 \%)$ & $(100 \%)$ \\
& & & \\
\hline
\end{tabular}

Table 4: The distribution of $\mathrm{ABO}$ and Rh blood groups in female subjects

Number of students (percentage)

\begin{tabular}{cccc}
\hline Blood group & Rh $+v e$ & Rh -ve & Total \\
\hline A & $\begin{array}{c}234 \\
(33.33 \%)\end{array}$ & $10(1.43 \%)$ & $244(34.76 \%)$ \\
& $\begin{array}{c}176 \\
\text { B }\end{array}$ & & \\
& $(25.07 \%)$ & $20(2.85 \%)$ & $196(27.92 \%)$ \\
O & $\begin{array}{c}210 \\
(29.92 \%)\end{array}$ & $6(0.85 \%)$ & $216(30.77 \%)$ \\
AB & $42(5.98 \%)$ & $4(0.57 \%)$ & $46(6.55 \%)$ \\
\hline Total & $(94.30 \%)$ & $40(5.70 \%)$ & $(100.00 \%)$ \\
\hline
\end{tabular}

\section{DISCUSSION}

The distribution of $\mathrm{ABO}$ and $\mathrm{Rh}$ blood groups vary from population to population. Available literature indicates that over 99\% Asian are $\mathrm{Rh}+\mathrm{ve}$ [3] but among our subjects 95.38\% were $\mathrm{Rh}+\mathrm{ve}$ and $4.62 \% \mathrm{Rh}-\mathrm{ve}$. It is close to the findings of Parmanik and Parmanik from Nepalese students in Nepal medical college, Kathmandu. Their subjects were $96.66 \% \mathrm{Rh}$ +ve and 3.33\% $\mathrm{Rh}$-ve [5]. $\mathrm{Rh}^{-}$blood group is documented as $5 \%$ in Nairobi [6], 4.5\% in Nigeria [7] and $7.7 \%$ in Rawalpindi studies [8].

The distribution of $\mathrm{A}, \mathrm{B}, \mathrm{O}$ and $\mathrm{AB}$ blood groups among European has been reported to be $42 \%, 9 \%, 46 \%$ and $3 \%$ respectively. But in our study subjects, $28.17 \%$ were blood group A, 30.17\% were blood group B, 34.87\% were blood group 0 and $6.79 \%$ were blood group $A B$. AB blood group is rare in our subject which is also true in students from Nepal medical college, Kathmandu. In them, blood group $\mathrm{A}$ was the commonest followed by $\mathrm{O}$ then $\mathrm{B}$ and $\mathrm{AB}$. But among our subjects, the commonest one is blood group 0 followed by $\mathrm{B}$ then $\mathrm{A}$ and $\mathrm{AB}$.

Such inconsistency of data suggests that further study or survey of blood groups in Nepalese population is essential to know the exact picture. Such types of survey or study will also be helpful in creating a blood-group directory, which can be used in calling the donor at the time of need. Such survey can also help to make the illiterate public aware of the essential of knowing blood groupings and blood donation.

\section{ACKNOWLEDGEMENTS}

Authors would like to thank all the students, faculty members and staffs of the department 
of Physiology, of all five medical colleges for their help and support. We would like to extend our special thanks to office assistant Sangita Sapkota for her support. We wish to thank guru Gorakhnath and Nikhileshwor for their blessings.

\section{REFERENCES}

1. Glass RI, Holmgren J, Haley CE et al. 1985. Predisposition for cholera of individuals with 0 blood group: possible evolutionary significance. American Journal of Epidemiology. 121:791-796.

2. Ernest Beutler, Marshall A. Lichtman, Barry S. Coller et al. 1995. Williams Hematology, $5^{\text {th }}$ edition. McGraw -Hill Inc. 1601-1602.

3. Ganong WF. 1993. Review of Medical physiology. $16^{\text {th }}$ edition. Norwalk CT, Appleton and Lange. 486-487.

4. Guyton AC, Hall JE. 2004. Text book of Medical Physiology. $10^{\text {th }}$ edition. Philaldelphia, Saunders.413-415.

5. Parmanik T, Parmanik S. 2000. Eastern Mediterranean Health Journal. 6(1):156-158.

6. Mawuagi J (1999). Blood group distribution in urban population of patient targeted blood donors. East Afr. Med. J. 76(11):615-618

7. Omotade 00, Adeyemo AA, Kayode CM, Falade SL, Ikpeme S (1999). Gene frequencies of ABO and $\mathrm{Rh}$ (D) blood group allele in a healthy infant population in Ibadan, Nig. West Afr.J.Med. 19: 294-297

8. Bhanti FA, Amin (1996). Spectrum of ABO and $D$ blood groups of donors at Rawalpindi/Islamabad. Pakistan J. Pathol. 7(2): 26-28. 